\section{Media coverage of a pandemic's impacts on farmers and implications for agricultural resilience and adaptation}

\author{
Douglas Jackson-Smith ${ }^{\text {* }}$ and Hadi Veisi ${ }^{b}$ \\ The Ohio State University
}

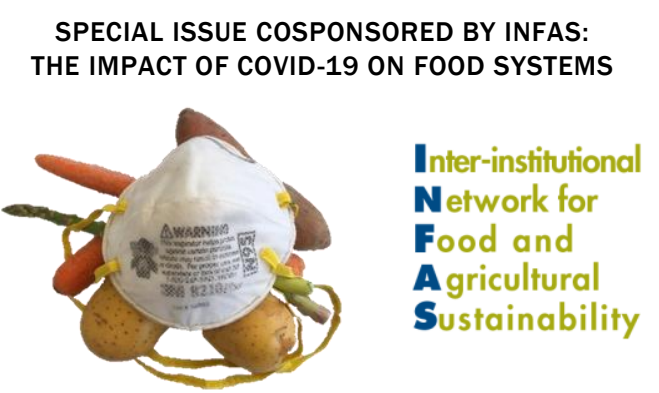

Submitted November 2, 2020 / Revised January 1 and January 24, 2021 / Accepted January 25, 2021 /

Published online April 1, 2021

Citation: Jackson-Smith, D., \& Veisi, H. (2021). Media coverage of a pandemic's impacts on farmers

and implications for agricultural resilience and adaptation. Journal of Agriculture, Food Systems, and

Community Development, 10(2), 157-179. https://doi.org/10.5304/jafscd.2021.102.039

Copyright (C) 2021 by the Authors. Published by the Lyson Center for Civic Agriculture and Food Systems. Open access under CC-BY license.

\begin{abstract}
The COVID-19 crisis has revealed weaknesses and placed great stress on the agri-food system in the U.S. Many believe that it could be a catalyst event that leads to structural changes to improve the food system's resilience. We use a sample of 220 articles published in prominent national newspapers and agricultural trade journals from March to May 2020 to explore the extent to which farmer responses to COVID-19 covered in the media represent examples of resistant, adaptive, or transformative strategies. The pandemic disrupted the U.S. food system and impacted farmers by reducing access to markets, lowering commodity

a* Corresponding author: Douglas Jackson-Smith, Professor and Associate Director, School of Environment and Natural Resources, The Ohio State University; 134 Williams Hall, 1680 Madison Avenue; Wooster, OH 44691 USA; +1-330-2023540; ذackson-smith.1@,osu.edu

b Hadi Veisi, Postdoctoral Researcher, School of Environment and Natural Resources, The Ohio State University; Veisi.1@,osu.edu
\end{abstract}

prices, restricting access to farmworker labor, and shifting consumer demand. Media coverage of farmer responses to these stressors were coded into three alternative pathways: (i) reactive or buffering responses, (ii) adaptive responses; and (iii) transformative responses. Most news media coverage focused on the pandemic's disruptive impacts on the U.S. food system, related negative impacts on farmers, and short-term responses by institutional actors, including policy-makers and food supply chain industry actors. Farmer responses to pandemic stressors were mentioned less frequently than farmer impacts and responses by institutional actors. The most common examples of farmer responses highlighted in the media reflected farmer reactive and buffering behaviors, which were mentioned significantly more frequently than adaptive or transformative

Funding Disclosure

We gratefully acknowledge funding from the U.S. National Science Foundation Innovations at the Nexus of Food, Energy, and Water Systems (INFEWS) grant SES-1739909. 
responses. National newspapers were more likely to cover farmer responses and present examples of adaptive and transformative strategies compared to agricultural trade journals. Our findings suggest that news media coverage in the early months of the pandemic largely characterized the event as a rapid onset 'natural' disaster that created severe negative impacts. Media devoted more attention to short-term policy responses designed to mitigate these impacts than to farmer responses (in general) or to discussion of the deeper structural causes of and potential solutions to the vulnerabilities revealed by the pandemic. In this way, both national newspaper and agricultural trade journal coverage seems to promote frames that reduce the likelihood of the pandemic becoming the seed of a more resilient system.

\section{Keywords}

Adaptation, Buffering Behavior, COVID-19, Pandemic, Farmers, Farming Systems, Framing, Impact Pathways, News Media Coverage, Resilience

\section{Introduction}

The COVID-19 outbreak in early 2020 created sudden and severe shocks to the U.S. food supply chain (Nicola et al., 2020). In mid-March 2020, stay-at-home orders led to a dramatic shift in the ways in which households purchased and consumed food (Bomey \& Tyko, 2020; Michelson, 2020). Additionally, reduced travel by U.S. residents translated directly into a lower consumption of ethanol, leading to dramatic impacts on demand for corn from U.S. farmers (Fatka, 2020a; Meyer, 2020). Changes in consumption patterns and outbreaks among food supply chain workers led to significant disruptions in food supply chains (Corkery \& Yaffe-Belany, 2020b; Hearden, 2020). The pandemic also disrupted international shipping and trade (Swoboda, 2020b).

The increased visibility of food system vulnerabilities and failures have led many observers to question whether the pandemic might serve as a catalyst event leading to a fundamental transformation of farming and food supply chains. In the first few months of the pandemic, a number of scholars and organizations used resilience frameworks to assess the vulnerabilities, impacts, and responses in food systems (Food and Agricultural Organization of the United Nations [FAO], 2020; Hilchey, 2020). The concept of 'resilience' refers to the ability of individuals, communities, or systems (particularly ecosystems) to 'bounce back' or sustain their essential functions in the face of disturbance (Folke, 2006; Gunderson \& Holling 2002; Walker, Holling, Carpenter, \& Kinzig, 2004). Resilience frameworks understand the world as a complex adaptive system. They focus on dynamic co-evolutionary processes in socio-ecological systems through which actors and institutions resist, adapt, or transform themselves in order to survive or thrive under uncertain or changing environmental conditions (Rammel, Stagl, \& Wilfing, 2007).

Questions about the resilience of modern agriculture and the global food supply chain began long before the COVID-19 pandemic (Ericksen, 2008; Kahiluoto et al., 2019; Puma, Bose, Chon, \& Cook, 2015). Nevertheless, many think the pandemic exposed the lack of social and ecological resilience of the dominant food system and predict significant transformations as part of a long-run social-ecological adaptive process (Kahiluoto, 2020; Worstell, 2020). Others are more sanguine and view it as an opening that will not necessarily generate deeper structural changes (Michelson, 2020; Moran, Cossar, Merkle, \& Alexander, 2020; Orden, 2020).

Key drivers of the resilience of a food system are the decisions and behaviors implemented by farm operators in response to changes in social, economic, and climate conditions. Darnhofer (2014) has developed a useful framework for categorizing the different capabilities or strategies farmers have that can contribute to their resilience. These include buffering (absorbing a perturbation without a change in structure or function by reallocating resources, mobilizing financial or labor reserves, or using excess capacity or inventory); adaptation (adjusting in a manner that adapts to new conditions while staying within the current regime, for example using new technologies or marketing channels, investing in storage, or pooling resources with other farmers); and transformation (implementing radical changes that lead to a transition to a 
new farming system, often through changes in farm enterprise type, establishing new production and marketing relationships, reorganizing the flow of labor and financial resources, and altering the balance of farm and off-farm activities).

Collectively, analyses of farm and food system resilience published in the early months of the pandemic provide useful and provocative hypotheses about the short- to long-term outcomes for food systems. However, most of these papers are conceptual and rely on limited empirical data or anecdotal information to construct their narratives or support their conclusions. While government statistics and primary research data takes time to be collected, processed, and released, much of what we know is through the window of media coverage of the event. Since the novel coronavirus first appeared, media outlets in the U.S. have published or produced thousands of articles and broadcast reports about the pandemic, many of which have focused on farming and the food system.

Media coverage is an important and 'real time' source of information about the world, but it also reflects the cognitive and cultural filters and biases of news reporters, media companies, and broader society (Murukutla, Kumar, \& Mullin, 2019; Shih, Wijaya, \& Brossard, 2008). Media coverage usually utilizes narrative frames that reflect and help reproduce dominant discourse and public understanding of important social, economic, and environmental problems (McEvoy, Fünfgeld, \& Bosomworth, 2013). Media framing studies have distinguished between generic-frames that represent crosscutting tendencies of the media to focus on particular questions, and issue-frames that highlight which aspects of a specific news topic are highlighted or ignored (Kozman, 2017). Typical generic frames in the media focus on the presence of conflict, attribution of responsibility, economic or material outcomes, human interest stories, and ethical or political morality dimensions of any topic (Semetko \& Valkenburg, 2000). Issue-frames provide concrete examples of how these generic frames are manifest surrounding a specific news issue, with an emphasis on media tendencies to "select some aspects of a perceived reality and make them more salient in a communicating text" (Entman, 1993, p. 52). Patterns of media coverage have been shown to impact public belief and enable or constrain processes of social change (Happer \& Philo, 2013).

There is relatively little published research on how news media covers pandemics or disease outbreaks. In one paper, Shih et al. (2008) note that news coverage typically shifts from documenting the source and spread of the disease to greater coverage of the impacts and societal responses. A portion of the largest and most systematic body of research on media coverage of sustainability and resilience topics comes from studies of how climate change has been framed in different news outlets. With respect to media coverage of agriculture, one recent study showed how coverage of the 2012 midwestern drought generally emphasized short-term impacts and recovery efforts, while downplaying connections to long-term climate change, thus minimizing the potential for generating adaptations that might increase resilience (Church et al., 2017). In addition, the authors found that some national newspapers (New York Times) were more likely to mention human-induced climate change in connection to the drought than other national newspapers (W all Street Journal) or agricultural trade journals (Church et al., 2020). In both cases, a lack of attention to broader structural changes in global climate dynamics served to reinforce the idea that short-term buffering or adaptive responses were most appropriate for farmers (rather than provoking more transformative changes in farming systems or practices).

Media coverage of farming and food issues are important in shaping how farmers, experts, decision-makers, and the general public think about challenges faced by the agricultural sector and the appropriate public policy responses (Cahill, Morley, \& Powell, 2010; McEvoy et al., 2013; Reisner \& Walter, 1994; Stevens, Aarts, Termeer, \& Dewulf, 2018). Accordingly, media coverage of the pandemic has created important frames that help people construct and represent meaning surrounding this particular external shock. These frames shape our understanding of how farmers, food system actors, and policy-makers have responded to the outbreak. In this paper, we present a systematic analysis of news media coverage of the impacts of the COVID-19 pandemic on farmers. We focus on 
issue-framing and explore how different media outlets highlight or downplay different aspects of the issue. Our analysis is explicitly guided by resilience concepts that focus attention on the ability of farmers to utilize buffering, adaptive, or transformative strategies to respond to the challenges presented by stressors and shocks like the pandemic (Darnhofer, 2014; Meuwissen et al., 2019). Specifically, we examine news media coverage to answer the following questions:

- How did news media describe the impacts of the crisis on farmers?

- How did news media characterize farmer responses to these impacts?

- How do national newspapers and agricultural trade journals differ in their coverage of the pandemic's impact on farmers?

- To what extent does news media framing encourage or frustrate a social-adaptive process leading to a more resilient farm and food system?

\section{Methods}

We employ a qualitative analysis of news media articles to document how they covered the impacts of the COVID-19 outbreak on U.S. farmers and the ways in which farmers and other food system actors responded in the early months of the pandemic. We systematically sampled news coverage from print media outlets that represent both mainstream national newspapers and industry-focused agricultural trade journals. We used content analysis methods to identify examples in media coverage of the impacts of the pandemic on farmers, and to categorize farmer responses to the pandemic into resistant, adaptive, and transformative categories.

\section{Sampling}

Instances of media coverage were identified using a systematic sampling of print news media articles indexed in the ProQuest LLC database. ProQuest LLC is a global information-content and technology company that archives newspapers, periodicals, and other media in a searchable database. To capture a representative range of national media frames, we initially conducted a full text query of the ProQuest databases for articles from three prominent national daily newspapers: The New York Times (NYT), the Wall Street Journal (WSJ), and USA Today (USAT). We utilized a keyword search to capture articles that included both terms related to agriculture ("Farmer" or "Farming" or "Agriculture") and terms related to the pandemic ("COVID-19" or "Coronavirus"). We limited our search to news articles published between March 1, 2020, and May 15, 2020, and content published in English. The newspapers included in our analysis are all considered reliable sources of information and represent a mix of moderate political biases, according to the nonprofit Ad Fontes Media (2020). We recognize that differences in political bias by media coverage can easily be overstated (Budak, Goel, \& Rao, 2016), but we feel that these three papers present a representative mix of perspectives (Feldman, Maibach, Roser-Renouf, \& Leiserowitcz, 2012; Gentzkow \& Shapiro, 2010) and have strong national visibility and reputations for objectivity compared to more polarized outlets (Boykoff \& Boykoff 2004).

To capture the types of media coverage that are more likely to be seen or read by farmers and other agribusiness actors, as opposed to the general public, we also queried the ProQuest database of Agricultural Trade Journals (ATJs) for news articles using the same keywords that were published over the same time period. ATJs in the ProQuest database primarily include nationally syndicated articles published in a network of 'regional' or 'commodity' magazines by The Farm Progress Network (FPN) (e.g., Southeast Farm Press, Southwest Farm Press, Western Farm Press, Farm Industry Needs, Corn and Soybean Digest, Beef, and National Hog Farmer). These articles represent a mix of original journalistic content from network reporters and material submitted to the FPN from independent journalists, farm organizations, and applied academic researchers and extension personnel. Frequently the same article was published simultaneously across multiple magazine outlets by the network. Because nearly $90 \%$ of unique articles meeting our criteria in the ProQuest ATJ database came from magazines in the network, we limited our analysis to FPN magazines. While similar ratings of the reliability and potential bias of ATJs was not determined, based on previous published research 
we assume that they reflect perspectives and editorial biases that are pro-industry and 'leaning conservative' (Church et al., 2020).

After eliminating duplicate versions of the same articles from the newspapers and ATJs, a sample of 735 nonduplicate examples of print media was produced (Table 1). Both authors then screened each of these articles to remove stories that (a) were not news coverage (e.g., op-eds, commentaries, or obituaries; $n=26$ ), (b) focused only on impacts outside of the U.S. ( $n=53)$, (c) addressed topics outside of our focus area (e.g., were spurious and did not include any mention of COVID-19's impacts on agriculture or food; $n=285$ ), or (d) only addressed COVID-19's impacts on other aspects of the U.S. food supply chain, but did not include any mention of farmer impacts or responses $(n=151)$. In total, $68 \%$ of the articles that met our initial search criteria were excluded, resulting in a final sample size of 220 unique instances of news media coverage that addressed COVID-19 impacts on U.S. farmers and agriculture and/or farmer or food system responses to these impacts.

\section{Data Analysis and Coding}

Content analysis is typically a reflective and iterative process whereby analysts code for the presence and absence of key themes or concepts in written text or transcribed discourse (Erlingsson \& Brysiewicz, 2017). We utilized an applied deductive design in which research questions and initial theoretical categories (such as Darnhofer's resistance capability categories) were used to direct the initial coding phase, but an inductive process allowed the final coding categories to evolve to better reflect the content found in the articles (Beal, 2013; Elo \& Kyngas, 2008). We (both authors) began by reading and rereading the text from our full useable sample of media articles to understand the range of perspectives and content. We then conducted an open coding of examples of sentences or paragraphs within each article into categories or themes within each of three focused topics: (a) information about how pandemic shocks to the U.S. farm and food system directly or indirectly impacted farm operators and farm families (FARM IMPACTS); (b) examples of how farmers responded to these impacts (FARMER RESPONSES); and (c) information about other short-term policy and market reactions to COVID-19's impacts on the farm sector (SUPPLY CHAIN RESPONSES). Examples within each of these three coding themes were then organized into a set of emergent subthemes (axial coding) that were reflective of the data but informed and shaped by concepts from the resilience frameworks outlined above. For example, when coding for farmer responses, we looked for examples of farmer responses to the pandemic's impacts that represented buffering, adaptive, and transformative strategies. Within each of those categories, we identified clusters of similar material that represented more specific subthemes.

To ensure validity and reliability in the coding process, open and pattern coding was done itera-

Table 1. Number of Articles in Sample Based on Inclusion and Exclusion Criteria

\begin{tabular}{|c|c|c|c|c|c|c|}
\hline Characteristic & NYT & USAT & WSJ & $\begin{array}{l}\text { Combined } \\
\text { Newspapers }\end{array}$ & ATJs & Full Sample \\
\hline Nonduplicate Sample Size & 186 & 178 & 81 & 445 & 290 & 735 \\
\hline \multicolumn{7}{|l|}{ Disqualified (by reason) } \\
\hline Not News (op-ed, obituary, etc.) & 12 & 3 & 0 & 15 & 11 & 26 \\
\hline No U.S. focus & 36 & 2 & 10 & 48 & 5 & 53 \\
\hline $\begin{array}{l}\text { Off-Topic (no discussion of COVID-19 } \\
\text { and U.S. food/ag system) }\end{array}$ & 94 & 112 & 21 & 227 & 58 & 285 \\
\hline $\begin{array}{l}\text { Other COVID-19-Food Supply Chain } \\
\text { Focus (but did not include farmers) }\end{array}$ & 22 & 19 & 17 & 58 & 93 & 151 \\
\hline Total disqualified & 164 & 136 & 48 & 348 & 167 & 515 \\
\hline Percent disqualified & $88 \%$ & $76 \%$ & $59 \%$ & $78 \%$ & $58 \%$ & $70 \%$ \\
\hline Qualified Sample Size & 22 & 42 & 37 & 102 & 123 & 220 \\
\hline
\end{tabular}


tively and reflexively by both authors to gradually identify areas of disagreement and to clarify the criteria for classification in the final theme assignments (Lai \& To, 2015; Miles, Huberman, \& Saldaña, 2014). Specifically, each article was coded and revisited several times to verify that each body of selected text was coded accurately into the final categories. In the presentation of results below, we select a few representative examples from the full set in each category to illustrate the deeper meanings behind each of our coded themes and subthemes. We also tabulate the number of media articles from each source that included one or more examples of each coded theme. All of these steps help increase the trustworthiness of the study (Elo, Kääriäinen, Kanste, Pölkki, Utriainen, \& Kyngäs, 2014).

The full sample of media articles included coverage of COVID-19 impacts and farmer responses from across the U.S. Most examples described events or quoted farmers from identifiable locations, and we coded these by state whenever possible. Overall, the combined sample included at least one example of farmer impacts or farmer responses from 34 different states. Both national newspapers (29 states) and ATJs (22 states) presented examples from most major agricultural areas in the U.S.

\section{Results}

\section{Impacts on Farmers}

Efforts to control the virus inevitably caused a range of economic and social shocks that affected the functioning of agricultural and food systems (Stephens, Martin, van Wijk, Timsina, \& Snow, 2020). Our analysis of national newspapers and agricultural trade journal coverage identified 135 articles that presented information about the direct impacts of the pandemic on farmers (Table 2). These were coded into five main subthemes: loss of market access, depressed income, loss of farmworkers, increased demand for certain types of products, and direct impacts on farmer health and well-being. The frequency of different subthemes in national newspapers and ATJs is shown in Table 2. While national newspapers in our sample were slightly more likely to include examples of direct impacts on farmers ( $65 \%$ vs $59 \%$ ), this difference was not statistically significant. However, the types of impacts covered in each type of media did vary in important ways.

\section{Loss of market access}

Changes in food consumption patterns and supply chain disruptions caused many farmers to lose access to key markets for their farm products. Our newspaper sample was significantly more likely to highlight examples of loss of market access associated with these food system shocks. Overall, 39\% of newspapers provided examples, compared to $18 \%$ of ATJ articles. Among articles from each source that highlighted any examples of farmer impacts, newspapers included information about market access problems twice as often $(60 \%$ of the time compared to $31 \%$ ).

Examples of market shocks included instances where disruptions in processing plants and distribution networks associated with the shift from food service to food retail outlets resulted in farmers being unable to sell their milk, livestock, and fresh fruits and vegetables (e.g., Bradley, 2020ATJ). ${ }^{1}$ One article reported on a dairy processing plant that was unable to take milk from farmers due to a disruption of transport and distribution networks, and quoted one farmer as saying "There are not a lot of other places to go with it if your buyer can't take it" (Bunge, Maltais, \& Newman, 2020 NwP, p. 2). Many stories highlighted bottlenecks caused by closure of meat packing plants due to illness among workers (Molina, 2020NwP; Radke, $\left.2020 \mathrm{a}^{\mathrm{AT} J}\right)$. In one example, reporters noted that "...pork producers face the possibility of...the loss of $25 \%$ of the nation's processing capacity as meatpacking plants have slowed or closed due to COVID-19" (Eller, 2020b ${ }^{\text {NWP }}$, p. 3).

Farmers who previously relied on direct sales to large institutions and restaurants were also affected by sudden loss of access to their traditional markets (O'Leary, 2020ATJ; Severson,

\footnotetext{
${ }^{1}$ To enable the reader to track the media sources for individual examples presented in this section, we have used superscript tags to reflect the four media outlets: "NWP" for newspapers and "ATJ" for agricultural trade journals.
} 
Table 2. Number and Percent of Articles Coded on Each Theme, by Source

\begin{tabular}{|c|c|c|c|c|c|c|c|c|c|c|c|c|c|c|c|c|}
\hline \multirow[b]{2}{*}{ Content Theme } & \multicolumn{3}{|c|}{ Combined Media Sample } & \multicolumn{3}{|c|}{ New York Times } & \multicolumn{3}{|c|}{ USA Today } & \multicolumn{3}{|c|}{ Wall Street Journal } & \multicolumn{3}{|c|}{ Trade Journals } & \multirow[b]{2}{*}{$\begin{array}{c}X^{2} \\
p \text {-value }\end{array}$} \\
\hline & Count & $\begin{array}{l}\% \text { of all } \\
\text { coverage } \\
\text { from } \\
\text { source }\end{array}$ & $\begin{array}{c}\text { \% of } \\
\text { coverage } \\
\text { within } \\
\text { major } \\
\text { category }\end{array}$ & Count & $\begin{array}{l}\% \text { of all } \\
\text { coverage } \\
\text { from } \\
\text { source }\end{array}$ & $\begin{array}{l}\% \text { of } \\
\text { coverage } \\
\text { within } \\
\text { major } \\
\text { category }\end{array}$ & Count & $\begin{array}{l}\% \text { of all } \\
\text { coverage } \\
\text { from } \\
\text { source }\end{array}$ & $\begin{array}{c}\% \text { of } \\
\text { coverage } \\
\text { within } \\
\text { major } \\
\text { category }\end{array}$ & Count & $\begin{array}{l}\% \text { of all } \\
\text { coverage } \\
\text { from } \\
\text { source }\end{array}$ & $\begin{array}{c}\% \text { of } \\
\text { coverage } \\
\text { within } \\
\text { major } \\
\text { category }\end{array}$ & Count & $\begin{array}{l}\% \text { of all } \\
\text { coverage } \\
\text { from } \\
\text { source }\end{array}$ & $\begin{array}{c}\% \text { of } \\
\text { coverage } \\
\text { within } \\
\text { major } \\
\text { category }\end{array}$ & \\
\hline $\begin{array}{l}\text { Stressors Associated with the } \\
\text { Pandemic }\end{array}$ & 140 & $54 \%$ & & 11 & $48 \%$ & & 27 & $64 \%$ & & 26 & $70 \%$ & & 76 & $48 \%$ & & 0.045 \\
\hline Impacts on Farmers & 147 & $57 \%$ & & 14 & $61 \%$ & & 23 & $55 \%$ & & 26 & $70 \%$ & & 84 & $54 \%$ & & 0.301 \\
\hline A Loss of Market Access & 63 & $24 \%$ & $43 \%$ & 9 & $39 \%$ & $64 \%$ & 16 & $38 \%$ & $70 \%$ & 13 & $35 \%$ & $50 \%$ & 25 & $16 \%$ & $30 \%$ & 0.001 \\
\hline C Loss of Farm Labor & 19 & $7 \%$ & $13 \%$ & 2 & $9 \%$ & $14 \%$ & 3 & $7 \%$ & $13 \%$ & 5 & $14 \%$ & $19 \%$ & 9 & $6 \%$ & $11 \%$ & 0.434 \\
\hline $\begin{array}{l}\text { D Increased Demand for Some } \\
\text { Products }\end{array}$ & 22 & $8 \%$ & $15 \%$ & 5 & $22 \%$ & $36 \%$ & 5 & $12 \%$ & $22 \%$ & 6 & $16 \%$ & $23 \%$ & 6 & $4 \%$ & $7 \%$ & 0.004 \\
\hline $\begin{array}{l}\text { E Farmer and Household Health } \\
\text { and Well-being }\end{array}$ & 16 & $6 \%$ & $11 \%$ & 2 & $9 \%$ & $14 \%$ & 3 & $7 \%$ & $13 \%$ & 2 & $5 \%$ & $8 \%$ & 9 & $6 \%$ & $11 \%$ & 0.938 \\
\hline Farmer Responses & 96 & $37 \%$ & & 16 & $70 \%$ & & 23 & $55 \%$ & & 17 & $46 \%$ & & 40 & $25 \%$ & & 0.000 \\
\hline $\begin{array}{l}\text { A Farmer Reactive or Buffering } \\
\text { Responses }\end{array}$ & 79 & $31 \%$ & $82 \%$ & 12 & $52 \%$ & $75 \%$ & 22 & $52 \%$ & $96 \%$ & 13 & $35 \%$ & $76 \%$ & 32 & $20 \%$ & $80 \%$ & 0.000 \\
\hline 2 Hunkering down & 27 & $10 \%$ & $28 \%$ & 5 & $22 \%$ & $31 \%$ & 7 & $17 \%$ & $30 \%$ & 5 & $14 \%$ & $29 \%$ & 10 & $6 \%$ & $25 \%$ & 0.045 \\
\hline 3 Debt relief bankruptcy & 13 & $5 \%$ & $14 \%$ & 5 & $22 \%$ & $31 \%$ & 2 & $5 \%$ & $9 \%$ & 1 & $3 \%$ & $6 \%$ & 5 & $3 \%$ & $13 \%$ & 0.002 \\
\hline B Farmer Adaptive Responses & 25 & $10 \%$ & $26 \%$ & 9 & $39 \%$ & $56 \%$ & 5 & $12 \%$ & $22 \%$ & 3 & $8 \%$ & $18 \%$ & 8 & $5 \%$ & $20 \%$ & 0.000 \\
\hline $\begin{array}{l}1 \text { Adjust direct sales to be } \\
\text { socially distanced }\end{array}$ & 8 & $3 \%$ & $8 \%$ & 5 & $22 \%$ & $31 \%$ & 2 & $5 \%$ & $9 \%$ & 1 & $3 \%$ & $6 \%$ & 0 & $0 \%$ & $0 \%$ & 0.000 \\
\hline $\begin{array}{l}2 \text { On-farm PPE use and social } \\
\text { distancing }\end{array}$ & 12 & $5 \%$ & $13 \%$ & 1 & $4 \%$ & $6 \%$ & 3 & $7 \%$ & $13 \%$ & 2 & $5 \%$ & $12 \%$ & 6 & $4 \%$ & $15 \%$ & 0.829 \\
\hline 3 Other adaptive & 6 & $2 \%$ & $6 \%$ & 4 & $17 \%$ & $25 \%$ & 0 & $0 \%$ & $0 \%$ & 0 & $0 \%$ & $0 \%$ & 2 & $1 \%$ & $5 \%$ & 0.000 \\
\hline C Farmer Transformative & & & & & & & & & & & & & & & & \\
\hline Responses & 11 & $4 \%$ & $11 \%$ & 5 & $22 \%$ & $31 \%$ & 2 & $5 \%$ & $9 \%$ & 3 & $8 \%$ & $18 \%$ & 1 & $1 \%$ & $3 \%$ & 0.000 \\
\hline $\begin{array}{l}1 \text { Institutional direct shift to } \\
\text { individual direct }\end{array}$ & 10 & $4 \%$ & $10 \%$ & 4 & $17 \%$ & $25 \%$ & 2 & $5 \%$ & $9 \%$ & 3 & $8 \%$ & $18 \%$ & 1 & $1 \%$ & $3 \%$ & 0.001 \\
\hline $\begin{array}{l}2 \text { Conventional farms starting } \\
\text { direct sales }\end{array}$ & 3 & $1 \%$ & $3 \%$ & 1 & $4 \%$ & $6 \%$ & 1 & $2 \%$ & $4 \%$ & 1 & $3 \%$ & $6 \%$ & 0 & $0 \%$ & $0 \%$ & 0.158 \\
\hline Farm and Food System Responses & 145 & $56 \%$ & & 14 & $61 \%$ & & 31 & $74 \%$ & & 19 & $51 \%$ & & 81 & $52 \%$ & & 0.066 \\
\hline Total & 259 & $100 \%$ & & 23 & $100 \%$ & & 42 & $100 \%$ & & 37 & $100 \%$ & & 157 & $100 \%$ & & \\
\hline
\end{tabular}


$\left.2020^{\text {NWP }}\right)$. In one story, a farmer who manages 10,000 acres said that "The demand [from the large customers] just went to zero... and not only did we lose restaurants and schools, but people were going to the grocery store buying nonperishable stuff to put in the pantry. They were not buying leafy greens" (Kesling, 2020 NWP , p. 1). In another article, a farmer who relied on sales to restaurants reported that "...demand for our products evaporated by $70 \%$ almost overnight" (Newman, 2020b NWP , p. 1). Meanwhile, a senior analyst was quoted as saying that "school shutdowns will affect the approximately $7 \%$ of fluid milk consumed by school lunch programs, $\ldots$ and a drop-off in restaurant activity will cut into the $40 \%$ of cheese sold to food service outlets" (Bunge, Maltais, Newman, $2020^{\text {NWP }}$, p. 2).

\section{Income losses: Declining commodity prices, rising costs} of production

COVID-19 was a demand-side shock that reduced demand faster than producers could cut supply, adversely affecting the prices of many crop and livestock products. The most common type of impact reported in our media sample addressed the loss of farm income (included in $28 \%$ of newspaper and $38 \%$ of ATJ articles). Farmers quoted in the media often focused on low prices for their products. In one typical example, a grain farmer was quoted as saying "The pricing specifically on corn and soybeans have just been decimated" (Walsh, 2020ATJ, p. 3). Referencing an Iowa cattle producer, another article noted that "with the current market disruption, his family will lose US $\$ 250$ to US $\$ 300$ per head. Cattle prices have fallen $25 \%$ to $30 \%$ since January" (Eller, $2020 \mathrm{a}^{\mathrm{NWP}}$, p. 3). Experts in much of the media coverage validated these farmer reports. The $W$ all Street Journal reported that "Prices for corn, cattle, hogs and milk have dropped as demand from restaurants, colleges, schools and other institutions has evaporated. Production on farms was already high, meaning the nation started the crisis with stockpiles" (Gasparro, Kang, \& Stamm, 2020NwP, p. 1). A senior analyst for agricultural lender Rabobank reported that "Dairy farmers face the prospect of milk prices collapsing by as much as
$25 \%$ this year, falling to levels last seen during the 2008 financial crisis" (Bunge, Maltais, \& Newman, $2020^{\text {NWP }}$, p. 1). Another analyst predicted that future price declines would be about " $12 \%$ for corn, soybean 7\% and cattle 25\%" (Maltais, 2020bNWP, p. 4).

To make matters worse, costs of production for many producers went up in the early months of the pandemic. Constraints on international trade led to a spike in fertilizer prices (Knorr, 2020 ATJ), while the closure of ethanol plants forced dairy and beef producers who had relied on distiller's grain (a byproduct of ethanol production) to find more expensive feed alternatives (Maltais, 2020a ${ }^{\text {NWP }}$ ). The net effect was a major drop in projected net income for U.S. farmers. Several articles reported dramatic drops in producer economic outlook indices (SWP, 2020a ${ }^{A T J}$; Swoboda, 2020a ${ }^{A T J}$ ), and several articles reported net losses reaching the tens of billions in 2020 (N. Anderson, 2020NWP; Fatka,

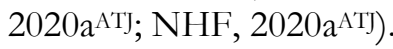

\section{Loss of farm labor}

In the initial weeks of the pandemic, immigration restrictions and embassy closures designed to prevent cross-national movement of the virus were imposed by the U.S. government, threatening the supply of immigrant farm workers. Farmers quoted in our sample of media articles often expressed concern about impacts on their workforce (Hart, 2020 ${ }^{\text {ATJ; Newman, 2020a }}{ }^{\text {NWP }}$ ). One major U.S. potato grower stated, "We're in a terrible fix if they shut the Mexican border off' because his operation relies heavily on immigrants holding temporary farm-work visas (Bunge, Maltais, \& Newman, $2020^{\text {NWP }}$ ). While less common than concerns about immigrant visas, news reports of illness among farmworkers disrupting farmers' ability to plant and harvest crops were not uncommon. One article noted that "In some cases, that glut could turn to a production crunch if the foreign migrant laborers that farmers increasingly rely on to pick produce and milk cows fall sick or stay home amid lockdowns to contain the virus" (Gasparro, Kang, \& Stamm, 2020NWP). Coverage of farm labor impacts was equally common across the two types of news media. 
Increase in demand for some products

While many large farms were negatively impacted by disruptions in conventional food supply chains and sales to global commodity markets, some media reports highlighted examples where smallerscale farms that market direct-to-consumers were flourishing under the pandemic (Barnard, $2020^{\text {NWP }}$. This type of positive impact on farmers was covered more frequently in national newspapers than in the ATJ sample. In one example, an agricultural economist was quoted as saying that "the lasting effect of the virus is to provide a new opportunity for local farming ... involvement in community-supported agriculture, often in the form of farmers markets, has 'blown up' in the last month. By buying direct from farmers, consumers cut out much of the complex supply chain that's causing problems during the virus" (Walsh, $2020^{\text {ATJ }}$, p. 3). Another farmer who markets through a New York farmers market reported that "Our sales are up 25 or 30 percent from what we would normally do this time of year" (Robey, $2020^{\text {NWP }}$, p. 1). While much of the coverage of increased demand focused on local foods, rising consumer demand for a few key products in grocery stores (flour, bread, peanut butter, rice, orange juice) led prices for a few mainstream commodities to increase during the early pandemic (Maltais \& Wallace, 2020 NWP; Zeitlin, $\left.2020^{\text {NWP }}\right)$.

\section{Direct impacts on farmer and farm household well-being} Finally, apart from impacts on farm businesses, media coverage of the pandemic included a few examples of direct impacts of the virus on farmer well-being. This includes the fact that many farmers are in high-risk categories for COVID-19 complications due to age and pre-existing conditions (Bechman, 2020ATJ; Smith, 2020a ${ }^{A T J}$ ). Farmers and their families also endured impacts of school closures (NHF, 2020b $\left.{ }^{A T J}\right)$, as well as anxiety, stress, and other mental health challenges (Barrett, 2020a ${ }^{\text {NWP }}$; Corkery \& Yaffe-Bellany, 2020b ${ }^{N W P}$; Smith, 2020 $\mathrm{b}^{\mathrm{ATJ}}$ ). One farmer pointed out that "I've tried to maintain a level of positivity as the COVID-19 pandemic continues to wreak havoc on our livelihoods, security, freedoms and mental and physical health. However, as this pandemic contin- ues, I've got my fair share of concerns. ... I'm a mom. I'm a rancher. I'm a consumer. I've got skin in the game here" (Radke, 2020b ${ }^{A T J}$, p. 1).

\section{Farmer Responses}

A total of 90 articles presented at least one specific example of farmer responses to COVID-19 impacts. Overall, both types of media were more likely to include descriptions of the impacts of the pandemic on farmers than on how farmers were responding to this crisis. However, coverage of farmer responses to the pandemic's impacts was much more frequent in national newspapers than in ATJs ( $58 \%$ vs. $28 \%$; Table 2). Farmer responses in the first few months to the stressors and impacts caused by the pandemic were coded into three categories that reflect examples of each of the three farmer capabilities outlined in Darnhofer's resilience framework: reactive, adaptive, and transformative. As she notes, "the term capability is used to denote that it is not an asset or an automatic response that can be deduced by the characteristics of the farm, but the ability to identify opportunities, to mobilize resources, to implement options, to develop processes, to learn as part of an iterative, reflexive process" (Darnhofer, 2014, p. 467).

\section{Farmer reactive or buffering responses}

Reactive or buffering responses were coded when we found examples of farmers seeking to cope with or temporarily buffer themselves from the immediate impacts of a stressor without changing their basic approaches to farming or marketing in any significant way. These examples reflect farmer efforts to minimize or absorb the impacts of COVID-19 without changing the commodities they raise or the outlets they use to sell their products. Reactive or buffering responses were by far the most common type of farmer response covered in our sample, accounting for over $80 \%$ of all articles that reported on any type of farmer response in both national newspapers and ATJs (Table 2). We clustered these into three buffering subthemes: destruction or disposal of farm products, seeking debt relief, and 'hunkering down.'

Destruction, disposal, or donation of farm products In the pandemic's first few months, a significant 
amount of media coverage (38\% of national newspaper articles and $15 \%$ of ATJ articles) highlighted examples of farmers dumping or destroying agricultural products. One article profiled a farmer in Arizona who experienced a 70\% drop in demand for his products and responded by destroying 250 acres of produce worth US $\$ 1.3$ million. In the farmer's words, "we're leaving perfectly good product in the field. ... It's a complete and total loss" (Newman, 2020b NWP). Another article described a major poultry company in Mississippi that responded to a $60-65 \%$ drop in demand from its restaurant customers by breaking eggs rather than hatching them and raising the chicks for slaughter (Severson, 2020 NWP). The New York Times reported on farmers in Idaho, Florida, and Georgia who buried millions of pounds of produce and noted that millions of gallons of milk-equivalent to $5 \%$ of U.S. daily production-were being discarded (Yaffe-Bellany \& Corkery, 2020NWP). A Wall Street Journal article related the case of two New York dairy farms that had to dump more than dozens of truckloads of milk because the cheese plant they sold to was unable to ship to restaurants and scaled down operations (Vielkind, 2020 NWP). The shutdown of meat processing plants forced some farmers to euthanize hogs that were at market weight but for which they had no outlet (Corkery \& Yaffe-Bellany, 2020a NWP).

Because of oversupplies and the closing of restaurant and institutional buyers, some farmers donated their products to food banks and other charities. One article shared the story of a New York dairy farmer who had a local processor bottle his milk in gallon containers that were given away through a local butcher shop (Bowman, 2020 NWP). Several articles highlighted efforts by Publix (a grocery chain) and Dairy Farmers of America (a dairy co-op) who organized efforts to deliver hundreds of thousands of pounds of produce and gallons of milk to food banks in several states (Fanning \&

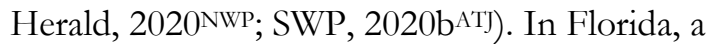
local farmer donated eight semi-truck loads of tomatoes to a local foodbank (B. Anderson, 2020NWP).

Debt payment relief, bankruptcy, and suicide The sudden shortfall in farm income contributed to media reports of farmers being unable to stay current on debt payments due to the coronavirus outbreak. In response, some farmers were highlighted for their efforts to seek debt relief from their lenders. One Iowa farmer told a reporter that "he's talked with his lender about deferring some principal payments on his debt for a year. Other farmers he's talked with are doing the same" (Eller, $2020 c^{\text {NWP }}$, p. 1). Some of the media coverage noted how the economic challenges associated with the pandemic were compounding pre-existing financial problems in the sector, which has led to a rise in farm bankruptcies (Barrett, 2020b ${ }^{\mathrm{NWP}}$ ). One article reported on rising suicides among Wisconsin dairy farmers (Searcey, 2020 NWP). In another story, a second-generation pig farmer from Minnesota who was trying to find ways to avoid killing a backlog of more than 1,000 pigs said, "There are farmers who cannot finish their sentences when they talk about what they have to do.... This will drive people out of farming. There will be suicides in rural America" (Corkery \& Yaffe-Bellany, 2020b ${ }^{\text {NWP }}$, p. 1).

\section{Hunkering down: Storage, slowing production, and cutting costs}

Finally, 25 articles (18\% of newspaper and $7 \%$ of ATJ articles), wrote about how farmers were planting crops and carrying on with business as usual in spite of the pandemic (Haire, 2020 ATJ). In the words of one farmer, they have little choice but to "hang on tight until things get better" (Leake, 2020 NwP , p. A1). Many stories reported on ways in which farmers were 'hunkering down' by storing fewer perishable products, slowing production, or cutting costs to weather the crisis. Grain farmers with on-farm storage were reportedly using it to hold onto their harvest until prices improved in the future (Lusk \& Croney, $2020^{\mathrm{ATJ}}$ ). Several articles reported on hog and cattle farmers who were altering diets for their herds to slow growth rates (Bagenstose, Bomey, \& Chadde, 2020 NWP $)$. Others noted that some dairy farmers were drying off cows early to reduce output (Torres, 2020ATJ). Finally, some news articles profiled examples of farmers seeking to cut costs by cutting workers, reducing input use, or simply 'hunkering down' to weather this period of intense stress (Newman, 2020c ${ }^{\text {NWP }}$; Wilson, 
$2020^{\mathrm{ATJ}}$ ). In one story, an Iowa farmer related how his multi-generational farm survived the Great Depression and 1980s Farm Crisis and noted that "My family has been farming here for over 100 years. I don't want to be the one to screw up" (Eller, 2020c NWP, p. 2).

\section{Farmer Adaptive Responses}

Adaptive responses are characterized by examples of farmers proactively seeking out ways to sustain farm income by making short-term incremental adjustments in their production or marketing practices to adapt to COVID-19 conditions, without changing their overall farming strategy. To be coded as an adaptive response, the responses had to have a sense of being temporary, meaning that farmers would likely go back to business as it was before the pandemic once COVID-19 disappears. We grouped examples into two main subthemes: adjusting direct sales to be more socially distanced and expanding protective measures like the use of PPE on-farm. Adaptive responses were much less widely reported than reactive and buffering responses, and they were more likely to be covered by national newspapers than ATJs (18\% vs. $5 \%$; Table 2).

\section{Adjust direct sales methods to be more socially distanced} Several articles highlighted examples of farmers who already sold directly to individuals and institutions exploring creative ways to adjust and expand these markets during the pandemic. All of these examples were found in national newspapers (e.g., none were covered in ATJs). One article stated that farmers markets were "transforming into laboratories for new communal safety habits... Shoppers cannot touch the produce and must stay six feet from one another. Tables must have plastic coverings. Workers must wear protective gear" (Barnard, 2020 NWP , p. 1). Berry growers in Tennessee reportedly set up drive-up options and socially distanced U-Pick approaches to reduce risks to farmers and customers (Hance, $\left.2020^{\text {NWP }}\right)$. Other stories profiled a farmer who had launched a new website to allow for online ordering in response to the temporary closure of his farmers market (Simon, 2020a), and a farm that had closed its farm stand and "retooled the farm's website to offer pickup options, so customers could show up, immediately get their vegetables and go home" (Robey, 2020NwP , p. 2). One California farm was highlighted because it had started "shipping produce boxes anywhere in the United States except Hawaii, via FedEx...But some shoppers are prepaying and driving to the farm, then waiting safely in their car with the trunk popped open, while the food is dispatched" (Rao, 2020NWP, p. 1).

\section{Expanded use of PPE on-farm}

In response to the potential loss of their farm labor force to the virus, some news media reported on examples of farmers requiring their workers to use personal protective equipment (PPE) and other protective measures. These types of on-farm adaptive responses were described in just over $10 \%$ of the news articles that covered any type of farmer response (in both national newspapers and ATJs). Two articles described efforts by specialty crop producers to require their immigrant workers to quarantine for two weeks, limiting their trips to grocery stores, and utilizing PPE (Newman, $2020 a^{\text {NWP}}$; Pratt, 2020ATJ). Others reported on large farms taking steps to create small groups of employees who would not interact to reduce the chance of large-scale impacts on their workforce (James, 2020NWP; Schrotenboer, 2020 NWP). Even farmers who rely primarily on family labor were presented as using adaptive measures to protect against on-farm spread of the virus (Ward,

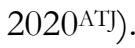

\section{Farmer Transformative Responses}

Transformative responses are when individual farmers responded to the pandemic by initiating fundamental and potentially long-term changes in their production or marketing practices that reflect a significant break from the past. In Darnhofer's words, "a transformation implies a transition to a new system... a qualitative change in which the farm adopts new basic operating assumptions, new 'rules of the game'..." (2014, p. 468-469). Our coding criteria sought examples of changes that we might expect to continue after the COVID-19 crisis (if they are successful). Compared to reactive and adaptive responses, we found very few 
examples of transformative farmer adaptations in our sample of news media articles. Any transformative adaptation examples were seen nearly exclusively in national newspapers (ATJs included only one example). Most common examples of transformative responses were cases where farmers who had previously sold their products directly to institutional buyers (schools, restaurants, etc.) reorganized their operations to sell directly to individuals. A few articles profiled conventional farmers who had always sold through mainstream commodity market channels who responded to the pandemic by initiating direct sales to individual customers.

\section{Shifting from institutional markets to direct sales to individuals}

Over the last 20 years, there has been rapid growth in the number of farmers who market directly to restaurants, schools, and other institutions. Farm suppliers to the 'farm-to-table' and 'farm-to-school' supply chains were directly affected by the sudden closure of these institutional buyers, and national newspapers covered numerous examples of farmers reconfiguring their marketing strategies to focus more on sales to individuals (either face-to-face or via online marketing channels). One article described a produce producer in New York City who had relied on restaurants for $60 \%$ of his business, but who collaborated with a wholesaler to start a home delivery system, using the trucks that used to supply restaurants to instead deliver directly to individual homes (Severson, 2020 NWP). Another article highlighted a small farm in California that usually sold its specialty produce to restaurants that shifted to preparing and distributing "prepaid boxes" to individuals (Rao, 2020 NWP). A third profiled a Florida poultry producer who had developed a profitable market selling custom-fit specialty birds to chefs and restaurants. "That came to a screeching halt' as COVID-19 began to infiltrate Florida, [the farmer] said. Then, the unthinkable happened: Crazy Hart Ranch began to see its best chicken sales in at least five years. 'Our sales have been pretty much off the charts...It's good for us,' she said, referring to other local producers she knows who have seen surging sales during the coronavirus pandemic. "We're all going crazy"'
(Leake, 2020NWP , p. 2). None of the ATJ articles described this type of farmer response.

\section{Conventional farms starting direct sales}

Both the national newspaper and the ATJ samples included at least one article highlighting conventional farmers who normally marketed through mainstream commodity channels, but who opened up to the public for U-pick and direct sales for the first time due to COVID-19 (Fanning \& Hearld, $\left.2020^{\text {NWP }}\right)$. One article described hog farmers in the Midwest who were selling live pigs to people over Facebook and Craigslist (Corkery \& Yaffe-Bellany, $\left.2020 b^{\text {NWP }}\right)$. Another described chicken processors who previously had shipped entirely to the food industry that were initiating sales of butchered birds directly to the general public out of the back of refrigerated trucks (Wernau, 2020NWP).

\section{Broader Food System and Policy Responses}

While roughly $60 \%$ of national newspapers and $30 \%$ of ATJ articles described examples of individual farmer responses to the stressors and impacts from the pandemic, a larger proportion of articles in each media source $(66 \%$ and $58 \%$, respectively; Table 2) presented examples of how other food supply chain industry and policy actors responded to the crisis to help ameliorate the impacts on farmers. We coded these institutional and structural responses into three categories: state and federal policy responses, market or industry responses, and advocacy by farm and other organizations for additional policy or structural changes.

Federal and state policy responses to help farmers address the impacts of the pandemic were covered in roughly $40 \%$ of both national newspaper and ATJ articles. Most common were reports about the extensive federal government programs that were designed to provide emergency financial aid to farmers such as the Coronavirus Aid, Relief, and Economic Security (CARES) Act; Paycheck Protection Program Loans (PPPL); and Coronavirus Food Assistance Program (CFAP). The federal government also expanded authority to the USDA Commodity Credit Corporation to provide another round of Market Facilitation Program (trade war) compensation payments and created programs to purchase food directly from farmers 
to distribute through food banks and other food assistance organizations (USDA Farmers to Families Food Box program). All told, by May 2020, the U.S. Congress had allocated US $\$ 23$ billion in direct aid to farmers and US\$3 billion to purchase fresh produce, dairy, and meat for distribution to food pantries (Fatka, 2020b ${ }^{\text {ATJ }}$ ). Stories about these federal farmer direct and indirect financial relief programs appeared in roughly $25 \%$ of both national newspaper and ATJ articles in our sample. Coverage of state programs was less common but there was mention of both a New York program to subsidize food processors to enable them to distribute surplus foods to needy families (Corkery \& YaffeBellany, 2020a ${ }^{\text {NWP }}$ ) and a California executive order to provide paid sick leave to farmers, farm workers, and other food system employees (Canon, 2020 NWP).

A significant amount of coverage (19\% of national newspapers and $15 \%$ of ATJ articles) reported on the use of Presidential executive orders to require the reopening of meat packing plants (e.g., Swanson \& Yaffe-Belany, 2020a ${ }^{\mathrm{NWP}}$ ) and on decisions to ease visa restrictions or relax minimum wage requirements for $\mathrm{H}-2 \mathrm{~A}$ immigrant farmworkers to ensure a supply of labor for farm work and meat processing (e.g., Pratt, 2020 ATJ).

In addition to describing state and federal policies that were adopted during this time frame, a sizeable number of articles reported on adjustments made by other food supply chain industry actors - mainly food processors and restaurantsin response to the pandemic. Food supply chain industry responses were quite common in national newspapers (covered in $37 \%$ of the articles) but only infrequently described in the ATJ sample (5\% of articles). Typical examples include providing food processing workers with PPE and other protections (Bagenstose, Chadde, \& Wynn, 2020NWP), retooling food processing facilities to adapt to changes in consumer food consumption behaviors (Bunge \& Newman, 2020 NWP), and making structural and management changes in restaurants and farmers markets to protect workers and customers from the spread of COVID-19 (Newman, 2020b ${ }^{N W P}$; Simon, 2020bNWP).

Finally, 34 articles (9\% of national newspapers and $20 \%$ of ATJ articles) had coverage of calls from politicians, farm organizations, and other groups seeking additional direct relief payments for farmers, structural changes in federal policies surrounding marketing of beef and dairy products, and other adjustments to state or federal farm programs. While most examples of advocacy focused on expanding traditional farm support programs, we identified 12 articles that reported on farmers and farm and food system activists who were advocating for deeper structural reforms to transform the U.S. farm and food system in response to the problems revealed by the pandemic. Examples included calls to address concentration in the meat packing industry (Fatka, 2020 $\mathrm{c}^{\mathrm{AT}}$ ), support for a wholesale overhaul of the U.S. farm programs (Khanna 2020ATJ), and criticism of large corporate farming (Anderson, 2020b NWP). Nearly all of the calls for more radical reform of the agri-food system appeared in the ATJ sample.

\section{Discussion and Conclusions}

The global coronavirus COVID-19 pandemic caused supply chain disruptions, changes in food consumption patterns, and altered immigration patterns, each of which impacted farmers both directly and indirectly (Stephens et al., 2020). Many scholars have written about how the pandemic revealed systemic vulnerabilities in our farming and food systems, and some have suggested that the pandemic could serve as a catalyst for fundamental changes in the organization of agriculture and food supply chains. While government datasets and other systematic primary research on COVID-19's impacts and farmers' responses are beginning to emerge, it has been common for academics and policy-makers to rely on journalists and mass media coverage to provide information about the ways the pandemic has affected farmers and food systems (Lusk et al., 2020). At the same time, decades of studies on media framing remind us that the media reports are not an unfiltered window into the world. The selection of topics and decisions to include certain voices and experiences while ignoring others reflect the influence of competitive commercial pressures, political power, and dominant societal discourses and cultures (Happer \& Philo, 2013).

Our systematic analysis of national print media 
coverage of the pandemic demonstrates that farming and food system topics received extensive attention and highlighted a wide range of issues in both national newspapers and agricultural trade journals. During the first three months of the outbreak, news reporters in these outlets were most likely to write about the economic shocks caused by the pandemic (and the public health policies that were adopted in response), with particular focus on how it changed food consumption patterns and disrupted food processing and supply chains. They also focused attention on the significant negative impacts of these economic shocks on farmers (a drop in demand from processors, loss of institutional markets, depressed commodity prices, and problems accessing farm labor). While most coverage highlighted negative impacts, a subset of articles described ways in which the pandemic increased demand for some products (mainly through a surge in local and/or direct sales to households). The emphasis on negative shocks and impacts is consistent with results of other media studies, where conflict and crises receive much greater coverage than stories about positive changes or outcomes (Shih, Wijaya, \& Brossard, 2008).

\section{Is There Evidence of Farmer Adaptive Behavior?}

The centerpiece of our study was to explore the extent to which media coverage provides evidence that the pandemic is precipitating deeper structural changes that could lead to a more resilient farm and food system. Using Darnhofer's (2014) resistance capacity framework, we looked for examples of three types of farmer responses to the pandemic which reflect different resilience pathways: buffering, adaptation, and transformation. We found that national newspapers were much more likely to cover farmer responses to the crisis than the agricultural trade journals (which focused more specifically on impacts on farmers and the larger policy or market responses, not individual farmer responses). Overwhelmingly, the most common examples of farmer responses covered in both types of media were buffering strategies: dumping or destroying products, seeking debt relief or filing for bankruptcy, or simply hunkering down by slowing production and cutting expenditures until the markets recovered. Buffering strategies reflect farmer efforts to weather the storm without making any fundamental changes in the types of commodities raised or marketing strategies used. Buffering strategies also reflect treatment of COVID19 as a short-term crisis in which actors expect to return to business as usual once the pandemic subsides.

At the same time, our sample included some articles and news reports of farmers using an adaptive strategy-particularly by small and mediumsized produce and livestock farmers who were better positioned to take advantage of the rapid rise in demand for food purchased directly from farmers through development of direct marketing outlets (e.g., online ordering, drive-by pickup, and home delivery). Adaptive responses were covered in about one in five national newspaper articles, but only one in 20 ATJ articles. Adaptive responses reflect efforts by farmers to adjust to changing patterns of consumer demand for food as well as the risks the virus poses to themselves and their farm workforce. These types of responses also appear to be short- or medium-term strategies that may well disappear once the pandemic recedes, rather than significant long-term changes in farming operations.

Interestingly, our review of these two types of news media did not identify many examples of farmers who were actively pursuing a more transformational pathway. There were virtually no articles or reports of people dramatically changing their farm enterprise mix or indicating plans to radically restructure their production and marketing practices for the long-term. The most common examples were stories about farmers who had previously invested heavily in direct sales to restaurants and institutions, who were restructuring their farms to focus more (or exclusively) on direct sales to individuals in the future. In three cases, coverage focused on mainstream conventional commodity farmers who were experimenting with direct sales to consumers (with some sense that this might be a part of their marketing strategy over the long run). All but one of the examples of transformative responses appeared in national newspapers (not ATJs).

While not a formal aspect of our analytical 
framework, we observed associations between how farmers were impacted by and responded to the pandemic, and key farm characteristics (particularly the perishability of commodities raised and relative reliance on conventional vs. alternative markets). For example, vegetable farmers from southern states whose products were ripe and ready for market in the spring were immediately hit by supply chain disruptions and were therefore more likely to be forced to destroy their crops. Similarly, dairy and livestock producers whose products were ready to sell were unable to hold their output until processors were able to reopen and accept their products. Meanwhile, farmers with less perishable crops (e.g., grain growers in the Midwest) were most often described as 'hunkering down'maintaining business as usual in their farming and cropping enterprises in the hope that they would be able to outlast the crisis. In all three cases, mainstream commodity farmers were described as adopting coping strategies that addressed the shortterm crisis, but few were described as making longterm changes that might make them less vulnerable to similar shocks in the future.

U.S. farmers who already sold directly to consumers appeared to be in a strong position to respond to the surge in demand for their products. Media coverage of their operations focused on ways in which they were able to adapt to the pandemic by implementing more socially distant methods to sustain this market in safe manner. In contrast, farmers who had organized their business model around sales to restaurants, schools, and other institutions were forced to innovate and adapt when these outlets closed and demand for their products fell. Unlike conventional commodity farmers, media stories about these 'alternative supply chain' oriented farmers included many more examples of adaptive and transformative farmer responses, particularly direct sales farmers who were able to adopt socially distanced sales, and institutional sales farmers who were able to refocus their attention on the growing individual direct sales consumer market.

The predominance of reactive and buffering responses by farmers in the media (and the relative absence of stories about farmers making more radical adaptive or transformative changes) may be partly because of massive federal short-term coronavirus aid programs that provided short-term compensation to farmers (particularly to those who sell in conventional mainstream markets) and executive orders by President Trump to reopen meat processing plants and ensure a supply of immigrant workers. Both of these institutional responses likely deflected pressures on U.S. farmers to consider more systemic changes in response to market shocks.

Taken as a whole, the narrative frames used in both national newspapers and ATJs reflect a bias toward short-term impacts and responses by individual farmers, with relatively little coverage engaging the possibility of long-term adaptive changes on farms and/or reflections on how systemic problems in the food system revealed by the pandemic might require transformative or structural solutions. This preference to frame the pandemic as a short-term crisis (rather than as evidence of deeper problems requiring a change in the status quo) is consistent with media framing used in reporting on climate change, flooding, and other natural disasters (Ford \& King, 2015; Happer \& Philo, 2013; Leitch \& Bohensky, 2014).

\section{Does Media Coverage Support or Slow Social- Adaptive Processes?}

Our study complements the large body of discussion and commentary essays that have explored the potential role of CV19 as a catalyst for increasing the resilience of food and farming systems. Given the nature of media coverage of the pandemic's impact on the U.S. farm sector, it is worth considering the role that news media play in accelerating or slowing broader social-adaptive processes that could lead to a restructuring of the farm and food system. Media studies scholars have long identified the important role that media has in shaping public understanding of important current issues and the range of alternative policy solutions that are considered reasonable or mainstream (Happer \& Philo, 2013). The important role of media in contemporary society has led to calls for better integration of research from mass communications and journalism fields into science and policy designed to improve social and environmental sustainability, particularly related to 
climate change adaptation (Lindenfeld, Smith, Norton, \& Grecu, 2014).

Our findings suggest that news media coverage in the early months of the pandemic in the U.S. has largely characterized the event as a rapid onset 'natural' disaster that created severe disruptions in food supply chains. The media therefore devoted more attention to the shortterm policy and market responses designed to mitigate these impacts than to farmer responses. Most coverage of farmer responses focused on immediate survival or adaptive strategies, with relatively little attention to examples of transformative responses that might reflect movement toward a reorganization of farming systems and/or commodity supply chains that could make the system more resilient in the future. This preference for treating the disaster as (a) outside of human control, and (b) a deviation from normal is similar to how media have covered floods and other natural disasters (Bohensky \& Leitch, 2014; Devitt \& O’Neill, 2017) and air pollution (Murukutla, Kumar, \& Mullin, 2019). As the crisis unfolds, however, it is possible that the media will shift attention to deeper analysis of the institutional and societal roots of food system vulnerabilities and stimulate public consideration of alternative institutions and structures (Kaufmann, Lewandowski, Choryriski, \& Wiering, 2016). In this way, media coverage seems to promote conservative frames that reduce the likelihood of the pandemic being the seed of a more resilient system.

We also found that the national newspapers cover the issue in ways that differ from the agricultural trade journals. Specifically, newspapers were more likely to highlight disruptions to traditional commodity markets and increased demand for direct sales than ATJs. Newspapers were twice as likely to cover any type of farmer response, and much more likely to include examples of adaptive or transformative responses than ATJs. While both outlets placed heavy emphasis on coverage of policy and market responses, national newspapers gave more attention to the adaptive strategies used by food processors and other supply chain actors, while ATJs were more likely to print articles highlighting calls for more transformative reform of the structure of agriculture or federal farm policies. Differences in patterns of coverage across these two outlets can exacerbate the gaps in understanding of food and agricultural issues between farmers and nonfarmers (Boogaard, Bock, Oosting, Wiskerke, \& van der Zijpp, 2011; Reisner \& Walter, 1994; Sharp \& Tucker, 2005). While the focus of our work was on traditional print media sources, it would be interesting to expand the analysis in the future to capture the role of social media (Stevens, Aarts, Termeer, \& Dewulf, 2018) and other alternative sources of news (like specialty magazines and e-journals).

In practice, the different farmer resilience pathways described in the first few months of media coverage of the pandemic likely reflect early stages in a cyclical or nonlinear process of adaptation to a major system shock. Although U.S. farmers were able to weather the pandemic's shocks and stressors initially through buffering behaviors, the experience may have deepened farmers' understanding of structural vulnerabilities of the dominant farm and food system. This experience could eventually contribute to a shift toward greater utilization of alternative food supply chains and open up new avenues for more 'generative' processes of resilience (Darnhofer, 2020). This could include expanding farmers' imagination of new possibilities in response to the unimagined level of crisis, and producing new ways of thinking, not only new structures (Grandori, 2020). Additionally, future work could explore the intersection of individual farmer responses and larger processes of change in political and economic structures. Khatri-Chhetri, Pant, Aggarwal, Vasireddy, and Yadav (2019) have suggested that resilience processes in complex systems should be examined across multiple-scales that capture the feedbacks between changes made at the individual, sectoral, and systems levels.

\section{References}

Ad Fontes Media. (2020). Media bias chart 6.1 November 2020 edition. Retrieved from https://www.adfontesmedia.com/static-mbc/ 
Anderson, B. (2020, May 14). To fight waste and hunger, food banks start cooking. The New York Times. Retrieved from https://www.nytimes.com/2020/05/14/dining/food-banks-free-meals-coronavirus.html?searchResultPosition=1

Anderson, N. (2020, April 15). US Farmers estimated to lose $\$ 20$ billion due to coronavirus crisis. US A Today. Retrieved from https://www.usatoday.com/story/money/business/2020/04/15/farmers-estimated-to-lose-billions-in2020/5136610002/

Bagenstose, K., Bomey, N., \& Chadde, S. (2020, April 30). Meat shortages expected as coronavirus disrupts production, despite executive order. USA Today. Retrieved from https://www.usatoday.com/story/news/2020/04/30/coronavirus-meat-shortages-expected-productionplunges/3052398001/

Bagenstose, K., Chadde, S., \& Wynn, M. (2020, April 22). Coronavirus at meatpacking plants worse than first thought, USA Today. Retrieved from https://www.usatoday.com/in-depth/news/investigations/2020/04/22/meat-packingplants-covid-may-force-choice-worker-health-food/2995232001/

Barnard, A. (2020, April 5). Farmers' markets help feed an uneasy city. The New York Times. Retrieved from https://www.blendle.com/i/time/farmers-markets-help-feed-an-uneasy-city/bnl-newyorktimes-20200405-41 1

Barrett, R. (2020a, April 1). Wisconsin farmers forced to dump milk as coronavirus slams a fragile dairy economy. Milwaukee Journal Sentinel. Retrieved from https://www.jsonline.com/story/money/2020/04/01/coronavirusforces-dairy-farmers-dump-milk-wisconsin-covid-19/5108609002/

Barrett, R. (2020b, April 14). Wisconsin farm bankruptcies rising rapidly as coronavirus weighs heavily on agriculture. Milwaukee Journal Sentinel. Retrieved from https://www.jsonline.com/story/money/2020/04/14/wisconsin-farmbankruptcies-rise-coronavirus-devastates-food-service/2984444001/

Beal, C. C. (2013). Keeping the story together: A holistic approach to narrative analysis. Journal of Research in Nursing, 18(8), 692-704. https://doi.org/10.1177/1744987113481781

Bechman, T. J. (2020, March 27). 6 ways COVID-19 impacts agriculture. Farm Industry News. Retrieved from https://www.farmprogress.com/farm-operations/6-ways-covid-19-impacts-agriculture

Bohensky, E. L., \& Leitch, L. M. (2014). Framing the flood: A media analysis of themes of resilience in the 2011 Brisbane flood. Regional Environmental Change, 14, 475-488. https://doi.org/10.1007/s10113-013-0438-2

Bomey, N., \& Tyko, K. (2020, April 20). Meat shortage 2020: Coronavirus has led Smithfield, other plants to close, farmers to dump milk. USA Today. Retrieved from https://www.msn.com/en-us/money/markets/meat-shortage2020-coronavirus-has-led-smithfield-other-plants-to-close-farmers-to-dump-milk/ar-BB12JHyz

Boogaard, B. K., Bock, B. B., Oosting, S. J., Wiskerke, J. S. C., \& van der Zijpp, A. J. (2011). Social acceptance of dairy farming: The ambivalence between the two faces of modernity. Journal of Agricultural and Environmental Ethics, 24(3), 259-282. https://doi.org/10.1007/s10806-010-9256-4

Bowman, S. (2020, May 7). Cows don't shut off: Why this farmer had to dump 30,000 gallons of milk. USA Today. Retrieved from https://www.usatoday.com/in-depth/news/2020/05/07/disruptions-pandemic-meant-dairyfarmer-spread-his-milk-his-indiana-land-coronavirus/3078296001/

Boykoff, M.T., \& Boykoff, J. M. (2004). Balance as bias: Global warming and the US prestige press. Global Environmental Change, 14(2), 125-136. https://doi.org/10.1016/i.gloenvcha.2003.10.001

Budak, C., Goel, S., \& Rao, J. M. (2016). Fair and balanced? Quantifying media bias through crowdsourced content analysis. Public Opinion Quarterly, 80(S1), 250-271. https://doi.org/10.1093/poq/nfw007

Bunge, J., Maltais, K., \& Newman, J. (2020, March 21). Coronavirus hits already frail U.S. farm economy: Corn farmers and cattle ranchers watch commodity prices drop, while produce growers fear labor shortages. The Wall Street Journal. Retrieved from https://www.wsj.com/articles/coronavirus-hits-already-frail-u-s-farm-economy-11584783001

Bunge, J., \& Newman, J. (2020, March 19). Coronavirus-era food supply: America has a lot. Moving it is tricky. The Wall Street Journal. Retrieved from https://www.wsj.com/articles/the-food-supply-u-s-has-a-lot-the-outbreak-makes-moving-it-tricky-11584631411

Cahill, S., Morley, K., \& Powell, D. A. (2010). Coverage of organic agriculture in North American newspapers: Media: Linking food safety, the environment, human health and organic agriculture. British Food Journal, 112(7), 710-722. https://doi.org/10.1108/00070701011058244 
Canon, G. (2020, April 16). Newsom: California to grant two weeks of paid sick leave for all food sector workers. USA Today. Retrieved from https://www.usatoday.com/story/news/politics/2020/04/16/coronavirus-california-foodsector-workers-get-2-weeks-paid-sick-leave/5146514002/

Church, S. P., Bentlage, B., Weiner, R., Babin, N., Bulla, B. R., Fagan, K., ... Prokopy, L. S. (2020). National print media vs. agricultural trade publications: Communicating the 2012 Midwestern US drought. Climatic Change, 161, 43-63. https://doi.org/10.1007/s10584-019-02630-3

Church, S. P., Haigh, T., Widhalm, M., de Jalon, S. G., Babin, N., Carlton, J. S., ... \& Prokopy, L. S. (2017). Agricultural trade publications and the 2012 Midwestern US drought: A missed opportunity for climate risk communication. Climate Risk Management, 15, 45-60. https://doi.org/10.1016/j.crm.2016.10.006

Corkery, M., \& Yaffe-Bellany, D. (2020a, April 19). The food chain's weakest link: Slaughterhouses. The New York Times. Retrieved from https://www-nytimes-com/2020/04/18/business/coronavirus-meat-slaughterhouses.html

Corkery, M., \& Yaffe-Bellany, D. (2020b, May 14). Meat plant closures mean pigs are gassed or shot instead. The New York Times. Retrieved from https://www.nytimes.com/2020/05/14/business/coronavirus-farmers-killing-pigs.html

Darnhofer, I. (2014). Resilience and why it matters for farm management. European Review of Agricultural Economics, 41(3), 461-484. https://doi.org/10.1093/erae/jbu012

Darnhofer, I. (2020). Farm resilience in the face of the unexpected: Lessons from the COVID-19 pandemic. Agriculture and Human Values, 37, 605-606. https://doi.org/10.1007/s10460-020-10053-5

Devitt, C., \& O’Neill, E. (2017). The framing of two major flood episodes in the Irish print news media: Implications for societal adaptation to living with flood risk. Public Understanding of Science, 26(7), 872-888. https://doi.org/10.1177/0963662516636041

Eller, D. (2020a, April 21). 'Horrible choices': Iowa livestock producers may have to euthanize pigs as packing plants struggle. Des Moines Register. Retrieved from https://www.desmoinesregister.com/story/money/agriculture/2020/04/21/coronavirus-meatpacking-slowdownforce-iowa-pork-producers-euthanize-pigs-covid-19/5164368002/

Eller, D. (2020b, April 22). Tyson says it will close pork processing plant in Iowa indefinitely during COVID-19. Des Moines Register. Retrieved from https://www.desmoinesregister.com/story/money/2020/04/22/coronavirus-tysoncloses-pork-processing-meat-packing-plant/3005152001/

Eller, D. (2020c, May 13). You're losing money everywhere': Iowa farmers try to hang on through COVID-19 pandemic. USA Today. Retrieved from https://www.usatoday.com/story/money/2020/05/11/iowa-farm-crisis-coronavirus-pandemic/3109039001/

Elo, S., Kääriäinen, M., Kanste, O., Pölkki, T., Utriainen, K., \& Kyngäs, H. (2014). Qualitative content analysis: A focus on trustworthiness. SAGE Open, 4(1), 1-10. https://doi.org/10.1177/2158244014522633

Elo, S., \& Kyngäs, H. (2008). The qualitative content analysis process. Journal of Advanced Nursing, 62(1), $107-115$. https://doi.org/10.1111/j.1365-2648.2007.04569.x

Entman, R. M. (1993). Framing: Toward clarification of a fractured paradigm. Journal of Communication, 43(4), 51-58. https://doi.org/10.1111/j.1460-2466.1993.tb01304.x

Ericksen, P. J. (2008). What is the vulnerability of a food system to global environmental change? Ecology and Society, 13(2), 1-18. https://doi.org/10.5751/ES-02475-130214

Erlingsson, C., \& Brysiewicz, P. (2017). A hands-on guide to doing content analysis. African Journal of Emergency Medicine, 7(3), 93-99. https://doi.org/10.1016/j.afjem.2017.08.001

Fanning, T. (2020, April 25). Publix to donate extra food, milk it buys from struggling farmers. Sarasota Herald-Tribune. Retrieved from https://www.news-press.com/story/money/small-business/2020/04/25/publix-donate-extrafood-milk-buys-struggling-farmers/3027546001/

Fatka, J. (2020a, April 3). COVID-19 has widespread impact on ag. Corn and Soybean Digest. Retrieved from https://www.feedstuffs.com/news/covid-19-has-widespread-impact-ag

Fatka, J. (2020b, April 18). Secretary Purdue outlines COVID-19 aid support. Western Farm Press. Retrieved from https://www.feedstuffs.com/news/secretary-perdue-outlines-covid-19-aid-support

Fatka, J. (2020c, May 6). Missouri court rules in favor of meat plants. Beef. Retrieved from https://www.feedstuffs.com/news/missouri-court-rules-favor-meat-plants 
Feldman, L., Maibach, E.W., Roser-Renouf, C., \& Leiserowitz, A. (2012). Climate on cable: The nature and impact of global warming coverage on Fox News, CNN, and MSNBC. The International Journal of Press/Politics, 17(1), 3-31. https://doi.org/10.1177/1940161211425410

Folke, C. (2006). Resilience: The emergence of a perspective for social-ecological systems analyses. Global Environmental Change, 16(3), 253-267. https://doi.org/10.1016/i.gloenvcha.2006.04.002

Food and Agricultural Organization of the United Nations (FAO). (2020). FAO COVID-19 response and recovery programme. https://doi.org/10.4060/cb0439en

Ford, J. D. \& King, D. (2015). Coverage and framing of climate change adaptation in the media: A review of influential North American newspapers during 1993-2013. Environmental Science \& Policy, 48, 137-146. https://doi.org/10.1016/j.envsci.2014.12.003

Gasparro, A., Kang, J., \& Stamm, S. (2020, April 29). Two months that tore apart the food chain. The Wall Street Journal. Retrieved from https://www.wsj.com/articles/two-months-that-tore-apart-the-food-chain-11588174236

Gentzkow, M., \& Shapiro, J. M. (2010). What drives media slant? Evidence from U.S. daily newspapers. Econometrica, 78(1), 35-71. https://doi.org/10.3982/ECTA7195

Grandori, A. (2020). Black swans and generative resilience. Management and Organization Review, 16(3), $495-501$. https://doi.org/10.1017/mor.2020.31

Gunderson, L. H., \& Holling, C. S. (2002). Panarchy: Understanding transformations in buman and natural systems. Washington, D.C.: Island Press.

Haire, B. (2020, March 23). COVID-19 not stopping Southern corn farmers kicking off 2020 planting. Southeast Farm Press. Retrieved from https://www.farmprogress.com/corn/covid-19-not-stopping-southern-corn-farmers-kicking-2020-planting

Hance, M. (2020, April 29). Strawberry farms welcome pickers and berry buyers. Nashville Tennessean. Retrieved from https://www.tennessean.com/story/life/2020/04/29/picking-strawberries-good-way-get-outside-and-enjoy-farmlife/3031713001/

Happer, C., \& Philo, G. (2013). The role of the media in the construction of public belief and social change. Journal of Social and Political Psychology, 1(1), 321-336. https://doi.org/10.5964/jspp.v1i1.96

Hart, J. (2020, March 20). Farmers discuss labor issue due to COVID-19, stress no food shortage. Western Farm Press. Retrieved from https://www.farmprogress.com/fruit/farmers-discuss-labor-issue-due-covid-19-stress-no-food-shortage

Hearden, T. (2020, April 29). Virus-related food shortages will be temporary in the U.S., experts say. Farm Industry News. Retrieved from https://www.farmprogress.com/farm-business/virus-related-food-shortages-will-be-temporary-us-experts-say

Hilchey, D. (2020). Open call papers and early responses to COVID-19. Journal of Agriculture, Food Systems, and Community Development, 9(3), 1-4. https://doi.org/10.5304/jafscd.2020.093.035

James, I. (2020, April 5). On vegetable farms, growers grapple with harvest demands and coronavirus risks. US A Today. Retrieved from https://www.usatoday.com/story/money/nation-now/2020/04/05/arizona-yuma-farms-growersgrapple-adapting-coronavirus/2951390001/

Kahiluoto, H. (2020). Food systems for resilient futures. Food Security, 12(4), 853-857. https://doi.org/10.1007/s12571-020-01070-7

Kahiluoto, H., Kaseva, J., Balek, J., Olesen, J. E., Ruiz-Ramos, M., Gobin, A., . . Trnka, M. (2019). Decline in climate resilience of European wheat. Proceedings of the National Academy of Sciences, 116(1), 123-128. https://doi.org/10.1073/pnas.1804387115

Kaufmann, M., Lewandowski, J., Chorynski, A., \& Wiering, M. (2016). Shock events and flood risk management: A media analysis of institutional long-term effects of flood events in the Netherlands and Poland. Ecology and Society, 21(4), Art. 51. https://doi.org/10.5751/ES-08764-210451

Kesling, B. (2020, April 26). Coronavirus forces farmers to destroy their crops. The Wall Street Journal. Retrieved from https://www.wsj.com/articles/coronavirus-forces-farmers-to-destroy-their-crops-11587909600 
Khanna, R. (2020, May 7). Transformational farm system reform act officially in both congressional chambers [Press release]. Retrieved from the Common Dreams website: https://www.commondreams.org/newswire/2020/05/07/transformational-farm-system-reform-act-officiallyboth-congressional-chambers

Khatri-Chhetri, A., Pant, A., Aggarwal, P. K., Vasireddy, V. V., \& Yadav, A. (2019). Stakeholders prioritization of climate-smart agriculture interventions: Evaluation of a framework. Agricultural Systems, 174, 23-31. https://doi.org/10.1016/j.agsy.2019.03.002

Knorr, B. (2020, April 7). USDA weighs in on pandemic impact. Southwest Farm Press. Retrieved from https://www.farmprogress.com/marketing/usda-weighs-pandemic-impact

Kozman, C. (2017). Measuring issue-specific and generic frames in the media's coverage of the steroids issue in baseball. Journalism Practice, 11(6), 777-797. https://doi.org/10.1080/17512786.2016.1190660

Lai, L. S., \& To, W. M. (2015). Content analysis of social media: A grounded theory approach. Journal of Electronic Commerce Research, 16(2), Art. 138. Retrieved from http://www.jecr.org/

Leake, L. (2020, May 4) Publix shelves bare? There's plenty of chicken, but it's packaged for food service not retail. Retrieved from https://www.tcpalm.com/in-depth/news/2020/05/04/coronavirus-pandemic-covid-19-floridafarm-poultry-chicken-meat/3039184001/

Leitch, A.M., \& Bohensky, E. L. (2014). Return to 'a new normal': Discourses of resilience to natural disasters in Australian newspapers 2006-2010. Global Environmental Change, 26, 14-26. https://doi.org/10.1016/j.gloenvcha.2014.03.006

Lindenfeld, L., Smith, H. M., Norton, T., \& Grecu, N. C. (2014). Risk communication and sustainability science: Lessons from the field. Sustainability Science, 9(2), 119-127. https://doi.org/10.1007/s11625-013-0230-8

Lubben, B. D. (2020, May 4). Reassessing farm income projections after COVID-19. Farm Industry Nens. Retrieved from https://www.farmprogress.com/farm-policy/reassessing-farm-income-projections-after-covid-19

Lusk, J., Anderson, J. D., Charlton, D., Coble, K., Davis, A., Dewey, A., .. Zilberman, D. (2020). Economic impacts of COVID-19 on food and agricultural markets (CAST Commentary QTA2020-3). Retrieved from https://www.cast-science.org/wp-content/uploads/2020/06/QTA2020-3-COVID-Impacts.pdf

Lusk, J., \& Croney, C. C. (2020, April 30). How is COVID-19 impacting the food supply chain? Beef. Retrieved from https://www.beefmagazine.com/business/how-covid-19-impacting-food-supply-chain

Maltais, K. (2020a, March 23). Cotton growers were recovering from trade war. Then coronavirus hit. The Wall Street Journal. Retrieved from https://www.wsj.com/articles/cotton-growers-were-just-recovering-from-trade-war-thencoronavirus-hit-11584967536

Maltais, K. (2020b, April 26). In another hit for farmers, coronavirus crushes ethanol market. The Wall Street Journal. Retrieved from https://www.wsi.com/articles/in-another-hit-for-farmers-coronavirus-crushes-ethanol-market-11587902400

Maltais, K., \& Wallace, J. (2020, March 30). Wheat and rice prices surge in coronavirus lockdown. The Wall Street Journal. Retrieved from https://www.wsj.com/articles/wheat-and-rice-prices-surgein-coronavirus-lockdown-11585598044

McEvoy, D., Fünfgeld, H., \& Bosomworth, K. (2013). Resilience and climate change adaptation: The importance of framing. Planning Practice \& Research, 28(3), 280-293. https://doi.org/10.1080/02697459.2013.787710

Meuwissen, M. P. M., Feindt, P. H., Spiegel, A., Termeer, C. J. A. M., Mathijs, E., de Mey, Y., . . Reidsma, P. (2019). A framework to assess the resilience of farming systems. Agricultural Systems, 176, Art. 102656. https://doi.org/10.1016/j.agsy.2019.102656

Meyer, G. (2020, March 26). Faltering ethanol refiners switch to hand sanitiser. Financial Times of London. Retrieved from https://www.ft.com/content/3aea9764-6e0c-11ea-89df-41bea055720b

Michelson, H. (2020, June 24). Opinion: A 'resilient' food system built on systemic vulnerabilities. Agri-Pulse. Retrieved from https://www.agri-pulse.com/articles/13975-opinion-covids-impact-on-the-american-food-system

Miles, M. B., Huberman, A. M., \& Saldaña, J. (2014). Qualitative data analysis: A methods sourcebook (3rd ed.). Thousand Oaks, CA: SAGE. 
Molina, B. (2020, May 2). Where's the beef... and the chicken: Should we worry about a meat shortage? USA Today. Retrieved from https://www.msn.com/en-us/news/other/wheres-the-beef-and-the-chicken-should-we-worryabout-a-meat-shortage/ar-BB13tYW5

Moran, D., Cossar, F., Merkle, M., \& Alexander, P. (2020). UK food system resilience tested by COVID-19. Nature Food, 1, Art. 242. https://doi.org/10.1038/s43016-020-0082-1

Murukutla, N., Kumar, N., Mullin, S. (2019). A review of media effects: Implications for media coverage of air pollution and cancer. Annals of Cancer Epidemiology, 3(3). https://doi.org/10.21037/ace.2019.07.03

National Hog Farmer (NHF). (2020a, April 13). Beset by tough markets, farmers now dealing with COVID-19 implications. Retrieved from National Hog Farmer website: https://www.nationalhogfarmer.com/business/beset-tough-markets-farmers-now-dealing-covid-19-implications

NHF. (2020b, April 30). Midwest house members request more aid for U.S. pork producers. Retrieved from National Hog Farmer website: https://www.nationalhogfarmer.com/legislative/midwest-house-members-request-more-aid-us-pork-producers

Newman, J. (2020a, March 31). The coronavirus challenges facing U.S. farms: Get workers, keep them healthy. The Wall Street Journal. Retrieved from https://www.wsj.com/articles/the-coronavirus-challenges-facing-u-s-farms-getworkers-keep-them-healthy-11585660358

Newman, J. (2020b, April 4). Closed because of the coronavirus, restaurants clear out their pantries. Wall Street Joumal. Retrieved from https://www.wsi.com/articles/closed-due-to-coronavirus-restaurants-clear-out-their-pantries-11586005203

Nicola, M., Alsafi, Z., Sohrabi, C., Kerwan, A., Al-Jabir, A., Iosifidis, C., ... Agha, R. (2020). The socio-economic implications o-f the coronavirus pandemic (COVID-19): A review. International Journal of Surgery, 78, 185-193. https://doi.org/10.1016/j.ijsu.2020.04.018

O’Leary, F. (2020, April 6). Farm groups urge USDA to help dairy farmers. Southeast Farm Press. Retrieved from https://www.farmprogress.com/dairy/farm-groups-urge-usda-help-dairy-farmers

Orden, D. (2020). Resilience test of the North American food system. Canadian Journal of Agricultural Economics, 68(2), 215-217. https://doi.org/10.1111/cjag.12238

Pratt, K. (2020, May 7). Kentucky growers educating H-2A workers to keep safe during pandemic. Southeast Farm Press. Retrieved from https://www.farmprogress.com/regulatory/kentucky-growers-educating-h-2a-workers-keep-safe-during-pandemic

Puma, M. J., Bose, S., Chon, S. Y., \& Cook, B. I. (2015). Assessing the evolving fragility of the global food system. Environmental Research Letters, 10(2), Art. 024007. https://doi.org/10.1088/1748-9326/10/2/024007

Radke, A. (2020a, March 18). COVID-19: How is the virus impacting U.S. agriculture? Beef. Retrieved from https://www.beefmagazine.com/management/covid-19-how-virus-impacting-us-agriculture

Radke, A. (2020b, April 13). COVID-19: As plants close; where's the meat? Beef. Retrieved from https://www.beefmagazine.com/beef-quality/covid-19-plants-close-wheres-meat

Rammel, C., Stagl, S., \& Wilfing, H. (2007). Managing complex adaptive systems-a co-evolutionary perspective on natural resource management. Ecological Economics, 63(1), 9-21. https://doi.org/10.1016/j.ecolecon.2006.12.014

Rao, T. (2020, April 4). A turn from supermarkets to small farm delivery. The New York Times. A.4. Retrieved from https://www.nytimes.com/2020/04/03/dining/csa-farm-food-delivery-coronavirus.html

Reisner, A., \& Walter, G. (1994). Agricultural journalists' assessments of print coverage of agricultural news. Rural Sociology, 59(3), 525-537. https://doi.org/10.1111/j.1549-0831.1994.tb00546.x

Robey, C. (2020, May 8). Small farms in N.Y. are experiencing a surprising boom. Here's why. The New York Times. Retrieved from https://www.nytimes.com/2020/05/08/nyregion/small-farms-ny-coronavirus.html

Schrotenboer, B. (2020, April 4). US agriculture: Can it handle coronavirus, labor shortages and panic buying? US $A$ Today. Retrieved from https://www.usatoday.com/story/money/business/2020/04/04/coronavirus-testsamericas-food-supply-agriculture/5096382002/

Searcey, D. (2020, April 11). 'Not as Wisconsin nice as we used to be': The divisions in dairyland. The New York Times. Retrieved from https://www-nytimes-com.proxy.lib.ohio-state.edu/2020/04/11/us/politics/wisconsin-politics.html 
Semetko, H. A., \& Valkenburg, P. M. (2000). Framing European politics: A content analysis of press and television news. Journal of Communication, 50(2), 93-109. https://doi.org/10.1111/j.1460-2466.2000.tb02843.x

Severson, K. (2020, April 9). The farm-to-table connection comes undone. The New York Times. Retrieved from https://www.nytimes.com/2020/04/09/dining/farm-to-table-coronavirus.html

Sharp, J. S., \& Tucker, M. (2005). Awareness and concern about large-scale livestock and poultry: Results from a statewide survey of Ohioans. Rural Sociology, 70(2), 208-228. https://doi.org/10.1526/0036011054776398

Shih, T. -J., Wijaya, R., \& Brossard, D. (2008). Media coverage of public health epidemics: Linking framing and issue attention cycle toward an integrated theory of print news coverage of epidemics. Mass Communication \& Society, 11(2), 141-160. https://doi.org/10.1080/15205430701668121

Simon, R. (2020a, March 21). For small businesses, it's a virus chain reaction. The Wall Street Journal. Retrieved from https://www.wsj.com/articles/for-small-businesses-its-a-virus-chain-reaction-11584763203

Simon, R. (2020b, May 2) Reimagining business after coronavirus: How one Cleveland restaurant's choices ripple through the economy. The Wall Street Journal. Retrieved from https://www.wsj.com/articles/putting-everything-onthe-table-a-cleveland-restaurateur-plots-a-way-forward-11588392002

Smith, R. (2020a, March 24). Farms, rural communities at risk for COVID-19. Southwest Farm Press. Retrieved from https://www.farmprogress.com/rural-health/farms-rural-communities-risk-covid-19

Smith, R. (2020b, March 27). Agriculture continues as COVID-19 threatens nation. Southeast Farm Press. Retrieved from https://www.farmprogress.com/rural-health/agriculture-continues-covid-19-threatens-nation

Southwest Farm Press [SWP]. (2020a, April 7). Ag economy barometer drops 47 points in March 2020. Retrieved from Farm Progress website: https://www.farmprogress.com/farm-life/ag-economy-barometer-drops-47-points-march-2020

SWP. (2020b, April 10). Dairy CORE program introduced as industry reels from COVID-19. Retrieved from Farm Progress website: https://www.farmprogress.com/dairy/dairy-core-program-introduced-industry-reels-covid-19

Stephens, E. C., Martin, G., van Wijk, M., Timsina, J., \& Snow, V. (2020). Impacts of COVID-19 on agricultural and food systems worldwide and on progress to the sustainable development goals. Agricultural Systems, $183,102873$. https://doi.org/10.1016/j.agsy.2020.102873

Stevens, T. M., Aarts, N., Termeer, C. J. A. M., \& Dewulf, A. (2018). Social media hypes about agro-food issues: Activism, scandals and conflicts. Food Policy, 79, 23-34. https://doi.org/10.1016/j.foodpol.2018.04.009

Swanson, A., \& Yaffe-Bellany, D. (2020, April 28). Trump declares meat supply 'critical,' aiming to reopen plants. The New York Times. Retrieved from https://www.nytimes.com/2020/04/28/business/economy/coronavirus-trump-meat-food-supply.html

Swoboda, R. (2020a, March 20). Cattlemen request help to cope with COVID-19. Corn and Soybean Digest. Retrieved from https://www.farmprogress.com/beef/cattlemen-request-help-cope-covid-19

Swoboda, R. (2020b, March 23). Virus creates trade deal uncertainty. Corn and Soybean Digest. Retrieved from https://www.farmprogress.com/trade/virus-creates-trade-deal-uncertainty

Torres, C. (2020, April 29). Dealing with dairy's black swan event. Southwest Farm Press. Retrieved from https://www.farmprogress.com/dairy/dealing-dairys-black-swan-event

Vielkind, J. (2020, April 29). New York dairy farmers feel the squeeze from coronavirus as milk sales dry up. The $W$ all Street Journal. Retrieved from https://www.wsj.com/articles/new-york-dairy-farmers-feel-the-squeeze-fromcoronavirus-as-milk-sales-dry-up-11588183989

Walker, B., Holling, C. S., Carpenter, S. R., \& Kinzig, A. (2004). Resilience, adaptability and transformability in socialecological systems. Ecology and Society, 9(2), 5. http://www.ecologyandsociety.org/vol9/iss2/art5

Walsh, D. (2020, April 19). Farm (maybe) to table: How coronavirus chopped the food chain in Michigan. Crain's Detroit Business. Retrieved from https://www.crainsdetroit.com/economy/farm-maybe-table-how-coronavirus-chopped-food-chain-michigan

Ward, M. (2020, April 21). Soybean farmers share struggles during pandemic. Southeast Farm Press. Retrieved from https://www.farmprogress.com/soybeans/soybean-farmers-share-struggles-during-pandemic 
Wernau, J. (2020, April 28). Cheese off a truck: Farmers try to salvage food, and some sales. The Wall Street Journal. Retrieved from https://www.wsi.com/articles/cheese-off-a-truck-farmers-try-to-salvage-food-and-some-sales-11588084929

Wilson, M. (2020, April 28). What remains after the storm? Southwest Farm Press. Retrieved from https://www.farmprogress.com/commentary/what-remains-after-storm

Worstell, J. (2020). Ecological resilience of food systems in response to the COVID-19 crisis. Journal of Agriculture, Food Systems, and Community Development, 9(3), 1-8. https://doi.org/10.5304/jafscd.2020.093.015

Yaffe-Bellany, D. \& Corkery, M. (2020, April 11). Dumped milk, smashed eggs, plowed vegetables: Food waste of the pandemic. The New York Times. Retrieved from https://www.nytimes.com/2020/04/11/business/coronavirus-destroying-food.html

Zeitlin, J. (2020, May 12). As coronavirus pandemic spikes orange juice sales, a Florida citrus grower gets squeezed. USA Today. Retrieved from https://www.usatoday.com/in-depth/news/2020/05/12/florida-citrus-florida-oranges-coronavirus/3093436001/ 